\title{
Recent judicial and legislative developments in the law of transfer of undertakings
}

\author{
by John McMullen
}

The author explains the passage of the new TUPE Regulations, and considers both the impact of recent cases and whether they are likely to be affected by the Regulations.

$\mathrm{N}$ wransfer of Undertakings ("TUPE") Regulations were laid before Parliament on February 7, 2006 in time for them to take effect on April 6, 2006 (the tortuous progress of these new Regulations is explained later in this article). These are known as the Transfer of Undertakings (Protection of Employment) Regulations 2006 (SI 2006/246) and replace the Transfer of Undertakings (Protection of Employment) Regulations 1981 (SI 1981/1794) and more fully implement Council Directive 2001/23/EC on the approximation of the laws of the Member States relating to the safeguarding of employees' rights in the event of transfers of undertakings, businesses or parts of undertakings or businesses (the "Acquired Rights Directive").

In the meantime, the summer of 2005 produced a harvest of interesting decisions on the existing law. Where these decisions are likely to be affected by the 2006 Regulations, we draw the reader's attention to that fact.

\section{THE DEFINITION OF TRANSFER OF AN UNDERTAKING}

One of the areas most affected by the new Regulations will be the definition of a transfer. But some principles concerning the definition of a transfer will be unaffected. One concerns the application of the principle in Ledernes Hovedorganisation (acting for Rygaard) V Dansk Arbejdsgiverforening (acting for Strø Mølle Akustik A/S) (ECJ Case C-48/94) [1996] IRLR 51 (the "Rygaard case") which holds that, in addition to being characterised as an economic entity retaining its identity, an undertaking, for the purposes of the legislation, must be a stable economic entity, ie something other than the performance of a single specified works contract (for detail, see McMullen, Business Transfers and Employee Rights, 5[126]).

\section{One-off contracts and the application of the Rygaard case}

In Mackie $v$ Aberdeen City Council (EATS/0095/04) the claimant claimed that her employment had been the subject of a TUPE transfer and that she had suffered from a relevant disability for the purposes of a separate claim under the Disability Discrimination Act 1995. In this article, we comment only on the former claim. In this case, the employee commenced employment with a company called Smartex Ltd in October 2002. Smartex had entered into a contract with Aberdeen City Council whereby it undertook to sub-contract with other suppliers to deliver to the Council an operational "smart card" system which would be used by the Council for the cash free payment of meals by school children and as a bus pass by senior citizens. The card was to be known as the "accord card". The contract was for a fixed price, for a fixed task and a defined product. The employee worked in Aberdeen, even though Smartex was a Cambridge based company. For the purposes of this project she worked on the Council's premises and was the only employee of Smartex working there. The work involved development and production of the accord cards and pilot projects prior to full implementation of the system. Towards the end of the fixed term contract the Council offered the claimant a job as Finance and Administrative Officer, which involved the administration of the accord card scheme. This was accepted. The employment tribunal found, however, that the new post involved matters which went beyond any tasks undertaken when she was in the employment of Smartex, notwithstanding that they were related to the accord card scheme. The employment tribunal therefore found that, in all the circumstances, there had been no TUPE transfer. There was no economic entity which could be the subject of a transfer. The contract with Smartex was a one-off matter for the production of a smart card and once that had been delivered, the business was at an end. And there was no transfer of an economic entity retaining its identity. 
On appeal, the EAT agreed. The analysis of the type of business carried on by Smartex as a "one-off contract" was a matter of fact for the employment tribunal. The EAT relied on the ECJ authority of Rygaard to the effect that the performance of a specific works contract could not amount to a stable economic entity capable of transfer. Furthermore, even if there had been a stable economic entity, on the facts of the case, the business had not retained its identity. As a final point in the case, it is true to say that when the claimant was taken on by the Council it was indicated to her by the Council that she was transferring under TUPE from Smartex. In Lightways Contractors Ltd v Associated Holdings Ltd [2000] IRLR 247 the EAT had considered that an employer's statement that an employee was being taken on under TUPE could be a relevant factor for a tribunal to consider in making a finding that there was, in law, a TUPE transfer (see, for detail, McMullen, Business Transfers and Employee Rights 5[173.3]). However, correspondingly, this did not mean that a statement that TUPE applied was conclusive of the matter. As the EAT said, in the present case: "the case of Lightways simply confirmed, perhaps not surprisingly, that if one party to a transfer has indicated an intention that TUPE will apply, that is an adminicle of evidence which can be taken into account since it may shed light on the true nature of the transaction. It is not, however, as at one point seemed to be suggested on behalf of the claimant, authority for the proposition that a party's statement that TUPE applies to the transfer is almost conclusive of the issue".

\section{The dichotomy between asset-reliant and labour intensive undertakings in the analysis of factors to be applied in deciding whether there is a transfer}

Since the European Court case of Ayse Süzen v Zehnacker Gebäudereinigung GmbH Krankenhausservice [1997] ICR 662 the European Court, when interpreting the seminal test of whether there is a transfer of an economic entity retaining its identity, contained in Spijkers v Gebroeders Benedik Abbatoir CV [1986] 2 CMLR 296 has tended to analyse whether a function being transferred is either labour intensive (in which case the importance is to be attached to whether there is a transfer of the workforce) or, on the other hand, asset reliant (where the determining factor may be whether assets have transferred). Süzen may be an example of the former, labour-intensive test. Oy Liikenne $A b \quad v$ Liskojärvi [2001] IRLR 171 is an example of the latter, asset reliant test. The problem with this twofold analysis is that some functions are not easily categorised into either asset reliant or labour intensive functions. (An example of the intellectual difficulty this can pose may be found in the ECJ case of Abler v Sodexho MM Catering Gesellschaft MbH [2004] IRLR 168). And in the UK, the British courts tend to prefer to take into account additional material, using the argument that the rich texture of the Spijkers test allows a multifactorial approach, allowing an employment tribunal in its fact finding exercise to draw on additional factors where appropriate (see, for examples of this, the Court of
Appeal decision in RCO Support Services Ltd $v$ UNISON [2002] ICR 751 (an otherwise labour intensive case) and $P$ \& O Trans European Ltd [2003] IRLR 128 and GEFCO UK Ltd v (1) Oates (2) Car and Delivery Co Ltd (EAT/0014/05) (both otherwise asset reliant cases)). The following case is the latest in this trend.

\section{The Scottish Coal company case}

In Scottish Coal Company Ltd v McCormack [2005] CSIH 68 the Court of Session queried whether it is necessary to characterise a function as, strictly, either asset reliant or labour intensive to the exclusion of other possibilities. In this case, Scottish Coal held a contract with Crouch Mining Ltd under which Crouch carried out mining activities at an opencast mining site in Ayrshire. Scottish Coal owned the coal deposits in the area and the arrangement with Crouch was for Crouch to mine it. The operations required the use of extremely heavy and expensive plant which was provided by Crouch and took the form of large excavating plant, each unit servicing around four or five large dumper trucks. In total there were four excavators and 15 dumper trucks together also with ancillary equipment. The value of this plant was in excess of $£ 2$ million. In addition to this plant, Crouch had erected on the site a workshop and office buildings with a canteen and shower area for the use of employees and the tribunal noted in evidence that the structures were worth around £150,000. In April 2001 Scottish Coal took over Crouch's activities at the site. Although Scottish Coal paid a relatively small sum for various fittings and fixtures left behind on site when Crouch departed Scottish Coal did not acquire Crouch's expensive plant as Crouch did not wish to sell in on to Scottish Coal. The majority of Crouch's employees were hired by Scottish Coal, carrying on the same mining activities they had carried out prior to the changeover.

The employment tribunal, relying on the guidance from the EAT in the case of Cheesman and Others $v R$ Brewer Contracts Ltd [2001] IRLR 144 found that there was the transfer of a stable economic entity from Crouch to Scottish Coal. It found that the workforce was specifically and permanently assigned to the task of mining and there was a sufficiently autonomous structure. Considering all of the factors characterising the transaction in question and noting that no single factor is to be considered in isolation, the tribunal found there was a transfer of an undertaking. The EAT upheld the employment tribunal's decision. It acknowledged that the function carried out by Crouch was asset reliant (the main assets of course being the plant and equipment rather than the buildings on site). However it distinguished the case of $O y$ Liikenne (where the absence of transfer of assets had been conclusive against a transfer). In this case a highly skilled workforce was carrying on an identical activity after the transaction and the tribunal had been entitled to reach the conclusion it did.

Scottish Coal appealed to the Court of Session. The central plank of its appeal was that the employment 
tribunal and the EAT had ignored the force of Oy Liikenne and the proper characterisation of Crouch's activities as asset reliant. Given that the function was so heavily asset reliant (see the value of the plant and equipment concerned above) the employment tribunal and the EAT should have found that, given the absence of transfer of these assets, there was no transfer. The Court of Session did not however accept Scottish Coal's central submission that a strict dichotomy between labour intensive functions and asset reliant functions had always to be maintained and that a business necessarily had to be characterised as one or the other. In its view there was nothing in the jurisprudence of the European Court, including the $\mathrm{Oy}_{\mathrm{y}}$ Liikenne case, which prevented the National Court from continuing to identify all relevant facts and circumstances in the case and weighing them in the balance.

Oy Liikenne could be explained, according to the Court of Session, as involving a set of facts at one end of the spectrum, so the inevitable conclusion was that the assets of the function concerned had to transfer before the Court could find a transfer of an undertaking. However, many cases will not easily fit within either asset reliant or labour intensive categories. These categories are neither mutually exclusive nor exhaustively definitive. According to the Court there is "a range of intermediate possibilities". Thus "Oy Liikenne and Abler were decided on the facts found in them. We do not read either case as laying down an invariable requirement that, in the context of a claimed TUPE transfer, a given business must necessarily be characterised as either "asset reliant" or "labour intensive", as if those were mutually exclusive categories which defined exhaustively the range of possibilities that could arise. The range of intermediate possibilities appears, $a$ priori, to be unlimited. The cases illustrate the position at one end of the spectrum when a transfer must include the production assets of the entity. In intermediate cases, it must always be an issue for the fact finding tribunal whether, on an appreciation of all relevant facts and circumstances, the undertaking in question can said to have been transferred for the purposes of the 1981 Regulations.”

As to the result in this particular case, the court's view was that the factual findings of the tribunal did not provide a proper basis on which to apply the guidance of the European Court. There were two main issues of concern for the court. First, the court stressed the need for careful examination of the economic realities of the undertaking under examination in the context of the particular industry in order to identify the essential characteristics of the undertaking in the context of a claimed TUPE transfer. In this case there were no findings of fact that reflected an appreciation by the tribunal of the economic realities of the arrangements for the provision of plant for use at the site. The relative importance of plant and labour in Crouch's operations was not analysed at all. Secondly, the tribunal had not analysed the importance of the transfer or non-transfer of supervisory and technical staff. In the appeal hearings it was assumed that the managerial and technical staff were not subsequently employed by Scottish Coal but the first instance employment tribunal had made insufficient findings of fact in relation to that and further, on the implications that might flow from such findings.

The complex debate about the application of European Court case law to the question of a transfer of an undertaking, in particular in relation to outsourcing (here the transaction may be characterised as the taking back in house of a previously outsourced service) and the difficulties of applying distinctions between asset reliant cases and labour intensive cases starkly illustrates the need for reform in this area. When the new TUPE Regulations come into force in April 2006 they will, in the main, provide that all service provision changes (including the taking of a service back in house) will be covered by TUPE without the need to determine whether the function is asset reliant or labour intensive.

\section{The European Court's decision in Güney-Görres v Securicor Aviation}

In the meantime, Güney-Görres v Securicor Aviation (Germany) Ltd (Case C-232/04) the Advocate-General of the European Court of Justice, Sr Poiares Maduro on June 16, 2005, gave, for the purposes of the Acquired Rights Directive, his initial opinion in a case where the transfer to (and subsequent use by) a transferee was also argued by the employer to be material to the question of transfer. In the case, Ms Güney-Görres and Ms Demir were employed by Securicor as security attendants carrying out security checks on passengers and their baggage at Düsseldorf Airport. Their employer carried out these tasks under a contract with the Bundes Ministerium des Inneren (BMI) of the German State. To carry out the contract BMI made available to Securicor the aviation equipment necessary to carry out the security checks on passengers, namely walk through metal detectors, a baggage conveyor belt with automatic x-ray screening (baggage checking system and screening devices), handheld metal detectors and explosive detectors. The attendants including the claimants had received training for their work on a special course of four weeks duration and had to pass an exam to qualify as an aviation security assistant and obtain the national accreditation required to perform the checks. In June 2003 the BMI notified Securicor that the contract at Düsseldorf airport would not be extended. At the end of the year this was awarded to Kötter Aviation Security $\mathrm{GmbH}$. Securicor gave notice to the claimants. Kötter took on 167 of the 306 employees employed by Securicor but not the claimants.

The Arbeitsgericht in Düsseldorf (Labour Court) considered that the function concerned was asset-reliant (comprising the security equipment referred to above). It also decided that the equipment was not used in an independent commercial manner as its maintenance was 
the responsibility of the German State, the contracting authority which also had to bear the cost. There was absolutely no scope for the relevant contractors to use the equipment for their own purposes. They could not obtain any independent economic benefit from it nor determine the manner and extent of its use. Furthermore under the contract, the contractor was obliged to use that specific equipment.

The Arbeitsgericht referred the following issue to the European Court. Does the transfer of assets from the original contractor to the new contractor presuppose their transfer for independent commercial use by the transferee? By extension is conferment on the contractor of a right to determine the manner in which the assets are to be used in its own commercial interest the essential criterion for a transfer of assets? The Advocate-General opined that "in examining whether there is a transfer of an undertaking or business within the meaning of the Directive, in the context of a fresh award of a contract the transfer of the assets for independent commercial use is not an essential criterion for a finding that there was a transfer of those assets from the original contractor to the new contractor".

On December 15, 2005, the Third Chamber of the European Court gave judgment in the same terms.

\section{ISSUES OF ASSIGNMENT TO THE UNDERTAKING}

It is a given that in order to claim transfer rights under TUPE, an employee has to be "assigned" to the undertaking or part transferred (see, in detail, McMullen, Business Transfers and Employee Rights, Chapter 6).

In Williams $v$ (1) Advance Cleaning Services Ltd (2) Engineering \& Railway Solutions Ltd (In Liquidation) (EAT/0838/04) the EAT considered an appeal from an employment tribunal on whether an employee was assigned to part of an undertaking transferred. Williams was employed by Engineering \& Railway Solutions Ltd (“E\&RS"). By 2002 Williams had been asked to take responsibility for what was described as the Company's "train care division". E\&RS had three contracts within that division. The London Terminals contract provided for cleaning services to South Central Trains operating out of London Bridge and Victoria. There was also an accommodation contract for cleaning the premises at the London Terminals and, finally, a cleaning contract for the trains running along the South Coast Eastwards from Hampshire.

It was the evidence that the London Terminals contract was difficult to administer in practice and took up a significant amount of Mr Williams' time. In 2003, however, South Central Trains decided to go through a process of retendering for the London Terminals contract. E\&RS submitted a tender but this was not successful. The contract was given to Advance Cleaning Services Ltd. Williams was not offered employment with Advance and, more or less immediately E\&RS went into liquidation (on a petition by the Revenue and the Customs \& Excise). Williams claimed unfair dismissal both against E\&RS (now in liquidation) and Advance Cleaning Services Ltd, the new contractor in relation to the London Terminals contract. The issue was whether Williams had been assigned to that part of the undertaking of E\&RS (the London Terminals contract) which was taken over by Advance. The employment tribunal accepted that Williams had spent $60 \%$ to $70 \%$ of his time on the London Terminals contract. It was therefore found as a fact by the employment tribunal that the London Terminals contract was the largest element in the work done by Mr Williams in the months leading up to the loss of the contract by E\&RS. However he was also responsible for the South East contract and the London accommodation contract. The employment tribunal therefore found that whilst it was satisfied that Williams spent a large part of his time, and maybe the majority of his time, working on the London Terminals contract, he continued to be an overall project manager in the employment of E\&RS. He never became an integral part of the London Terminals contract but remained attached to E\&RS and was available to undertake other work for them.

The EAT, on appeal by Williams, considered that the correct test to apply was that set out in the ECJ authority of Botzen v Rotterdamsche Droogdok Maatschappij BV [1986] 2 CMLR that "an employment relationship is essentially characterised by the link existing between the employee and the part of the undertaking or business to which he is assigned to carry out his duties. In order to decide whether the rights and obligations under an employment relationship are transferred under Directive $77 / 187$ by reason of a transfer within the meaning of Article 1(1) therefore, it is therefore sufficient to establish to which part of the undertaking or business the employee was assigned". The EAT considered that this was a question of fact and therefore, to succeed, Williams would have to show that the employment tribunal's decision was perverse. As the Court of Appeal had made clear in a different context, in Yeboah $v$ Crofton [2002] IRLR 634, perversity is "a high hurdle to jump". The EAT therefore considered that the findings of fact by the tribunal were unappealable. This authority adds to the many cases which emphasise that the amount of time spent by a person on certain duties simpliciter is not definitive of whether a person is assigned. The employment relationship, as a whole, has to be considered (see McMullen, Business Transfers and Employee Rights, Chapter 6).

\section{LEGISLATIVE AND POLICY DEVELOPMENTS}

There are a few important matters of note here. It is appropriate first to note the prolonged process of implementation of the new TUPE Regulations. 


\section{Implementing the new TUPE Regulations}

It is hard to believe that the process of revising the 1981 TUPE Regulations began as long ago as September 2001 (with a DTI consultation document on the subject of that date, followed by a policy position statement by the then Trade and Industry Secretary, Patricia Hewitt, in February 2003). The Government stated in its public consultation document URN05/926, issued on March 15, 2005 (discussed by the author in Amicus Curiae, Issue 59, May/June 2005, p1) that it had planned finally to lay the new draft TUPE Regulations before Parliament by July 1 , 2005, following the end of the consultation period on June 7. This would have enabled the Regulations to come into force on October 1, 2005. However the DTI's website subsequently stated that as a result of the large volume of responses to the consultation document, and the many issues that had been raised by respondents, ministers had decided to set a new timetable for finalising the Regulations. Consequently, the Department revised its plans, promising to lay the Regulations before Parliament in "Autumn" 2005, still bringing them into force on April 6, 2006. Even this revised target was not met; but the Regulations were eventually laid before Parliament on February 7, 2006, to come into effect on April 6, 2006. The Government had clearly underestimated the volume of response to the consultation document presupposing a swift turnaround would be manageable, in the light of its exhortation to consultees not to comment on policy issues, which had already been decided. But there was a wealth of technical material in the 2005 draft which needed some clarification and there were a large number of detailed responses on this subject, not just from individual consultees but from professional bodies. It is to be hoped that this lengthy reflection has finally produced a durable legal regime.

\section{Updated DTI Guidance on the handling of collective redundancies}

The DTI has produced an updated version of its leaflet, Redundancy Consultation and Notification (PL833). This may be downloaded from:

http://www.dti.gov.uk/er/redundancy/consult-pl833a.htm

The Guidance was updated following the ECJ judgment in Junk v Kühnel [2005] IRLR 310. The Guidance therefore makes it clear that consultation with employee representatives on redundancies should end before redundancy notices are issued (and not at the point the redundancy takes effect). The Guidance also includes a section on how collective redundancy legislation and information and consultation legislation interact. It also makes the important point that Stock Exchange Rules do not preclude employee representatives being informed and consulted in advance where collective redundancies are planned in connection with a restructuring (eg a planned closure or a takeover) which may involve price sensitive information.

\section{Revision of the Acquired Rights Directive}

The European Commission has issued a proposal to consult Social Partners and stakeholders on issues on conflict of laws/applicable law raised by the Acquired Rights Directive 2001/23. If proceeded with, the consultation will attempt to identify loopholes in the existing legislation with respect to questions of applicable law/conflict of laws where the transfer of undertaking coincides with a move of workplace to another Member State. At present, the Commission is undertaking informal consultations and welcoming views on aspects of the Acquired Rights Directive which are considered problematic and requiring amendment (see http://www.europa.eu.int/eur-lex/pri/en/oj/dat/2001/ 1_082/1_08220010322en00160020.pdf).

If proceeded with, the consultation may persuade the Commission to put proposals forward for revision of the Directive to deal with the difficult issue of transnational transfers of undertakings, including transnational outsourcing, where there is, presently, a lacuna in both the Acquired Rights Directive and in the TUPE Regulations themselves (see, for more discussion of this area, Evans, J "Offshoring Outsourcing: Is the Law Failing to Keep Up?" (2004) Employment Law Journal, pp8 to 10; McMullen, J "International Outsourcing and Transnational Transfers of Undertakings - a UK Perspective" (2005) The Company Lawyer, p 296; Hepple, B "The Legal Consequences of Cross Border Transfers of Undertakings within the European Union", Report for the European Commission, DGV (May 1998).

\section{Dr John McMullen}

Partner and Head of Employment Law at Watson Burton LLP, United Kingdom; (E-mail: john.mcmullen@watsonburton.com; Website: www.watsonburton.com) and Professor of Labour Law at the University of Leeds. He is the author of Business Transfers and Employee Rights (LexisNexis Butterworths, looseleaf, service and bulletins). 